\title{
Licensing of the Neutron Source in Ukraine: Challenges and Solutions
}

- Kukhotskyi O.V.

State Enterprise «State Scientific and Technical Center for Nuclear and Radiation Safety», Kyiv, Ukraine ORCID: https://orcid.org/0000-0002-0909-511X

- Bilodid I. I. State Enterprise «State Scientific and Technical Center for Nuclear and Radiation Safety», Kyiv, Ukraine ORCID: https://orcid.org/0000-0002-7790-2913

- Shepitchak A.V. State Nuclear Regulatory Inspectorate of Ukraine, Kyiv, Ukraine

- Nemtsova S. A. State Nuclear Regulatory Inspectorate of Ukraine, Kyiv, Ukraine

A research nuclear facility, the Neutron Source Based on the Subcritical Assembly Driven by a Linear Electron Accelerator (Neutron Source), is under commissioning in the National Scientific Center «Kharkiv Institute of Physics and Technology» (NSC KIPT), Ukraine, as an international collaborative project of NSC KIPT and the Argonne National Laboratory (ANL), USA. The Neutron Source is intended to study subcritical accelerator driven systems and generate neutrons to be used in applied and fundamental research in physics, chemistry, biology, and medicine. The construction of a state-of-art nuclear research facility is a challenge for both the operating organization (NSC KIPT) and the regulatory authority (SNRIU). NSC KIPT faced the technical challenges caused by the unique design features of the facility. SNRIU faced the two major challenges: no regulations to govern nuclear and radiation safety; no experience in licensing such a type of facility. This paper discusses aspects related to the challenges and solutions in licensing of the Neutron Source, including development of the regulatory and legal framework on nuclear and radiation safety, review of the safety justification documents for the new nuclear subcritical facility and verification calculations.

Ke y w o r d s: neutron source, experimental facility, licensing, safety.

○ Кухоцький О.В., Білодід Є.І, Шепітчак А.В., Немцова С.А. 2019

NSC KIPT, with support of the ANL, is constructing the subcritical accelerator driven dystem (ADS) facility «Neutron Source Based on the Subcritical Assembly Driven by the Linear Electron Accelerator» (Neutron Source). According to Article 1 of the Law of Ukraine «On Nuclear Energy Use and Radiation Safety» [1], the Neutron Source is a nuclear facility that requires all measures on its safety assessment and licensing. Under the implementation of the Neutron Source project in accordance with the Law of Ukraine "On Authorizing Activities in Nuclear Energy Use», the following separate stages of nuclear installation life are subject to be licensed: construction and commissioning; operation; decommissioning.

The licensing activities are carried out by the State Nuclear Regulatory Inspectorate of Ukraine (SNRIU) with the technical support of the State Scientific and Technical Center for Nuclear and Radiation Safety (SSTC NRS). 


\section{Design features of the Neutron Source}

The Neutron Source is an entirely new type of nuclear research facility where the rate of $235 \mathrm{U}$ isotope fission in the core is driven by an electron accelerator. The IAEA classifies such facilities as ADS (Accelerator Driven Systems) [2]. The target design applies tungsten or natural uranium for neutron production through photonuclear reactions from 100-MeV electrons. The layout and geometry of the SA core ensure that the effective neutron multiplication factor is not higher than $0.98\left(k_{\text {eff }}<0.98\right)$. Therefore, the self-sustaining chain fission reaction of $235 \mathrm{U}$ must not occur in the Neutron Source SA core [4], [5]. This approach ensures nuclear safety of such research facilities. This is the fundamental difference and advantage of the nuclear subcritical facility from nuclear research reactors, which are operated through self-sustaining fission chain reaction.

The Neutron Source consists of the following components (Fig. 1) [3] - [5]: subcritical assembly (SA) on thermal neutrons with shielding; neutron producing target (NPT) to produce primary neutrons, located inside the subcritical assembly core; linear electron accelerator (LEA) with a channel for beam transport; facility control panel; general engineering systems; test neutron channels for nuclear and physical research; engineering systems for the facility.

The NPT made from metal tungsten or natural uranium and located in the SA core center between

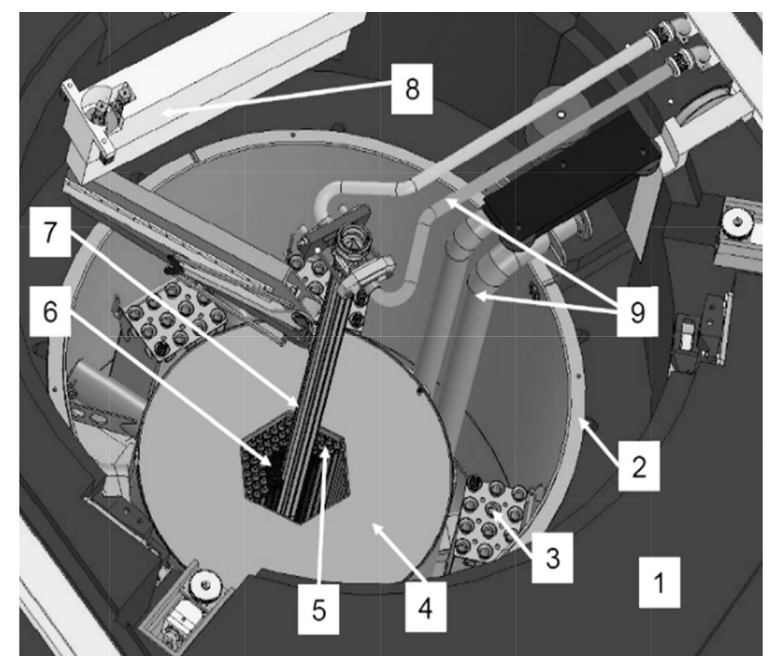

fuel assemblies is a source of external neutrons. The mechanism of neutron emission from the target is based on photonuclear $(\gamma, n)$-reaction which occurs after its irradiation by hard $\mathrm{\gamma}$-radiation with energy of $\gamma$-quantum, exceeding neutronbinding energy in target nuclei (8...10 MeV). Such F-radiation (deceleration, $y$-radiation) is generated during deceleration of high-energy neutrons (over $10 \mathrm{MeV}$ ) in material from heavy chemical elements. The linear electron accelerator is used to produce electrons with energy of $100 \mathrm{MeV}$, has average current $1 \mathrm{~mA}$ and beam power $100 \mathrm{~kW}$. A vacuum electron transportation channel with magnetic optics elements intended to focus the electron beam, change its direction and form necessary dimensions of the target irradiation area is used to transfer the beam from LEA to SA, which are spatially separated. The SA core consists of 37 fuel assemblies in case of a uranium target and 38 in case of a tungsten target, and is located in the subcritical assembly tank. The core is surrounded by a compound radial reflector consisting of beryllium units and an annular graphite reflector. The SA core uses nuclear fuel in fuel assemblies of VVR-M2 type with low enriched uranium with $19.7 \%$ of $235 \mathrm{U}$ isotope.

Normal operation of the main process equipment to receive and use neutrons is maintained by auxiliary control and support systems. The design envisages an automated control system (ACS) of the Neutron Source. ACS controls the state of facility systems, operating modes, diagnoses equipment malfunctions and failures and incompliance of parameters with

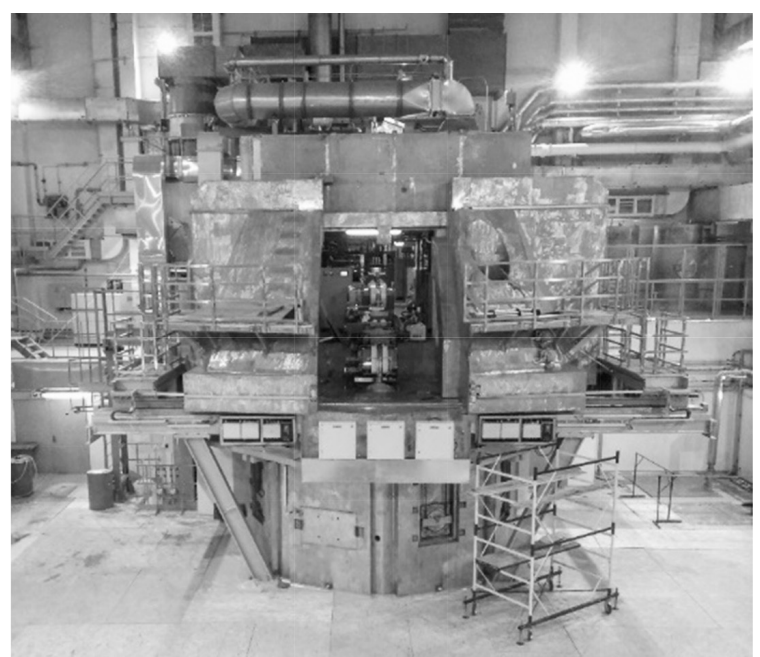

1 - biological shielding; 2 - SA tank; 3 - hanging racks; 4 - graphite reflector; 5 - beryllium reflector; 6 - core; 7 - target (NPT); 8 - refueling machine; 9 - core and target cooling circles

Fig. 1 - Neutron Source layout 
setpoints, provides relevant information to the operator, performs necessary tripping in accordance with the set of algorithms and interlocks. There is also an automated radiation monitoring system (ARMS) as an integral part of ACS. ARMS functions independently of other systems both during facility operation and in shutdown state (scheduled outage, maintenance, etc.). For removal of heat generated in the process equipment during the nuclear facility operation, several two-circle system are used for cooling of: the subcritical assembly ( $260 \mathrm{~kW})$, the target $(100 \mathrm{~kW})$. The LEA $(985 \mathrm{~kW})$ cooling system includes three subsystems of water cooling. Ventilation cooling towers of secondary cooling system ensure heat dissipation in the environment [3] — [5].

The Neutron Source is intended for scientific investigations of subcritical assemblies, generation of neutrons and their applications in nuclear physics, solid state physics, biology, generation of medical isotopes, radionuclide transmutations and training of experts in the nuclear energy.

\section{Neutron Source licensing}

The construction of the state-of-art nuclear research facility (Neutron Sources) is a challenge for both the operating organization (NSC KIPT) and the regulatory authority (SNRIU). NSC KIPT faced the technical challenges caused by the unique design features of the facility. SNRIU faced the two major challenges. First, there were no regulations to govern nuclear and radiation safety of such a type of facilities. Second, there was no experience in regulating the nuclear and radiation safety and licensing of such a type of facilities.

Development of regulatory framework on nuclear and radiation safety for the Neutron Source. Availability of the regulatory framework is the necessary condition of licensing process. At the beginning of the Neutron Source construction, the Ukrainian regulatory framework included only two valid former USSR's regulations with regard to SA:

Nuclear safety rules for subcritical stands (PBYa-01-75) put into force in 1975;

General safety provisions for research reactors during design, construction and operation (OPB IR) put into force in 1988.

Perceiving that the above mentioned regulatory requirements had to be revised considering state-ofthe-art IAEA standards and international experience, SNRIU in cooperation with SSTC NRS developed and brought into action the regulation «General Safety Provisions for Nuclear Subcritical Assembly» (GSP) [6].

The basis for the development of the GSP [6] was: accumulated national experience in research facilities, current regulatory requirements for nuclear power plants which were used applying the graded approach, as well as accumulated international experience, in particular the IAEA's developments for research facilities and subcritical systems, which were elaborated and published as SSR-3 «Safety of research reactors» [7] by the IAEA later.

The new regulation establishes the criteria and principles for safety of the nuclear subcritical facility, the requirements and conditions for ensuring nuclear and radiation safety at all stages of the life cycle of the nuclear subcritical facility, the main technical means and organizational measures aimed to protecting personnel, the population and the environment from possible radiation exposure. GSP [6] states that the main safety objective of the nuclear facility is to ensure protection of personnel, population and the environment against negative radiation impact of this facility during commissioning, operation and decommissioning. The nuclear facility will comply with the safety requirements if its radiation impact on personnel, the public and the environment under normal operation, operational occurrences and design-basis accidents is below the dose limits for personnel, the public, and the levels of permissible environmental releases.

The GSP [6] defines general requirements for all stages of the Neutron Source lifecycle. Some requirements should be specified in other lower level regulations (for example, safety requirements during tests at the Neutron Source). If foreign regulations are used, it is necessary to ensure harmonization of their requirements with Ukrainian law on nuclear and radiation safety. International regulations and rules may be used, if: a) their requirements are more conservative; b) the aspects that are not reflected in national regulations need to be addressed. Comparative analysis of regulatory documents (analysis of compliance) should be submitted to the SNRIU for consideration.

\section{Expert review of the Neutron Source documents}

In the Neutron Source's licensing process, SNRIU with the involvement of the technical support organization SSTC NRS performs an expert review 
of the licensing and operational documentation. The purpose of the nuclear and radiation safety expert review is to assess the compliance of the submitted materials with the requirements of nuclear and radiation safety regulations, rules and standards, as well as the assessment of the completeness, correctness, sufficiency and justification of the information provided. SSTC NRS has evaluated the Feasibility study, Preliminary Safety Analysis Report (PSAR) and Neutron Source Design at the first stage of licensing process. The following main conclusions were made as a result of the expert review.

The defense-in-depth strategy has been implemented in the Neutron Source. This strategy is based on a system of safety barriers to prevent releases of radiation and radioactive substances into the environment and a system of technical features and organizational measures to protect the safety barriers and preserve their efficiency. The safety barriers include the fuel rod and NPT claddings, primary system, confinement system.

The Neutron Source is designed to fulfill the principles of ensuring nuclear safety at all stages of Neutron Source life in accordance with the GSP [6]. The results of the calculations of subcriticality presented in PSAR [5] of the Neutron Source indicate that safety criteria are not exceeded during normal operation, operational occurrences and design-basis accidents.

The experience of the Fukushima-1 NPP accident was taken into account in the Neutron Source design (in the design-basis earthquake, safe shutdown earthquake (SSE) is 7 points according to the Medvedev-Sponheuer-Karnik scale (MSK-64), which provides an adequate supply of seismicity with respect to the seismicity of the site that is 6 points according to MSK-64 scale. As a part of the accident analysis, an assessment was carried out and the safety of the Neutron Source was proved in case of loss-of-heat-sink accident and total blackout. The Neutron Source cooling systems are designed as two-circle. The redundancy of equipment is provided, and passive flooding of SA during failure of operating and backup cooling pumps will be ensured. Coolant pressure in the primary circle is lower than operating pressure of cooling water in the secondary circle, which eliminates the possibility of radioactive coolant penetration into the secondary system in case of heat exchanging pipe leakage.

The cooling systems are systems of normal operation that are important to safety. The safety analysis of the subcritical assembly cooling systems failure indicates that the temperature of the nuclear fuel element cladding does not exceed the acceptance criteria.

On 26 September 2013, the SNRIU Board made a decision to issue a license to the NSC KIPT for construction and commissioning of the Neutron Source. It was granted on 10 October 2013 (License Series EO 001018). The above-mentioned license later was extended by SNRIU until 01 December 2020 .

Verification calculations. Licensing of new nuclear installations is impossible without using of various types of analytical tools for the verification safety analysis. Besides, IAEA recommends developing and using of independent expert models for regulatory safety assessment of nuclear installations. In the Neutron Source licensing process, SSTC NRS with the support of European experts (in frame of INSC projects [10]) developed the independent models of key nuclear facility elements and performed calculations for verification safety studies using non-identical analytical tools. The models of key nuclear facility elements were developed in the directions of neutron-physics calculations, thermal hydraulics safety analysis and radiation protection calculations.

Neutronic calculations. In order to confirm the calculations of subcriticality provided in PSAR [5] of the Neutron Source, the calculation models were developed. Neutronic verification calculations were performed with the SCALE code package [6]. Neutronic calculations covered the VVR-M2 fuel assembly, the subcritical assembly, the transport cask for fresh fuel and spent fuel storage facility. The calculations used standard 238-group library of the SCALE program package based on the ENDF/B-VI data files. Configuration of the subcritical assembly with 38 fuel assemblies was calculated for using of the NPT. The target itself was not modeled at this stage since its removal increases the multiplication properties of the SA. Using the average design fuel parameters, a good compliance of the results of the verification calculation and the result given in PSAR was obtained. At the same time, according to expert estimates, with the conservative consideration of changes in the parameters of fuel assemblies within the technological tolerances for their manufacture, $k_{\text {eff } \max }$ may exceed the permissible value of 0.98 . To resolve this issue, the number of the nuclear fuel assemblies, which are permitted to be loaded into the core, was limited to 35 nuclear fuel assemblies (instead of 38), with the subsequent justification of the possibility of increasing this number to 38 if $k_{\text {eff } \max }$ is not exceeded. 

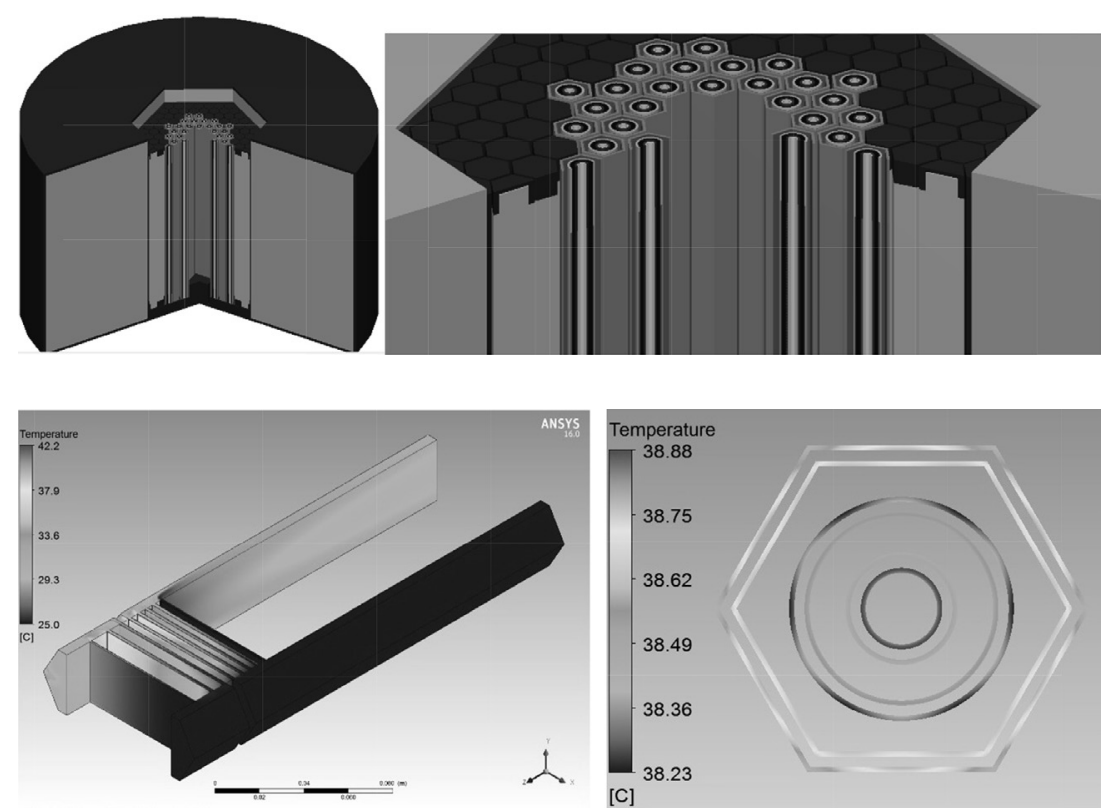

Fig. 2 - Isometric view of the SA

Fig. 3 - The results of the thermal hydraulic calculations of the NPT and nuclear fuel assembly
The criticality of the spent fuel storage pool was calculated with variation in the density of cooling fluid (water or water-air mixture). The obtained results are consistent with the results of the calculations in PSAR [5] and confirm a significant margin to achieve the safety criteria for the spent fuel storage pool in all operational modes.

Thermal hydraulic safety analysis. According to GSP [6], the Neutron Source safety is ensured by consistent implementation of defense-in-depth strategy based on the use of physical barrier system on the way of radiation and radioactive substance spreading to the environment, and system of technical means and organizational measures on protection of physical barriers and maintaining of their efficiency. Neutron Source physical barrier system on the way of radioactive substances and radiation spreading includes: fuel and NPT cladding, equipment of primary cooling circuits of the subcritical assembly and the NPT, confining system of leaktight compartments. The integrity criteria for the mentioned physical barriers are established and justified in Neutron Source PSAR [5]. Non-exceeding of the established criteria justified for all operating modes of the Neutron Source, emergencies and accidents. Accident management guides and their justifying documents were developed based on purposes not to reach or exceed criteria of physical barrier integrity. As it is shown by the integrity criteria, the following components of the Neutron Source are the key components affecting safety: NPT and the fuel assembly with claddings of aluminum alloy with the lowest melting temperature in the system. In order to perform independent verification calculations the technical support organization SSTC NRS are working to develop independent models of key «Neurons Source» components using other analytical tools [11]. Related to the verification of the safety criteria, two types of calculations are performed with the CFD code ANSYS CFX. The first one describes the NPT and the second one describes the fuel assembly. Geometries, meshing, boundary conditions are summarized and calculations are carried out for steady state normal operation and few accident transients. Comparison of the results with the PSAR shows comparable temperatures of the neutron

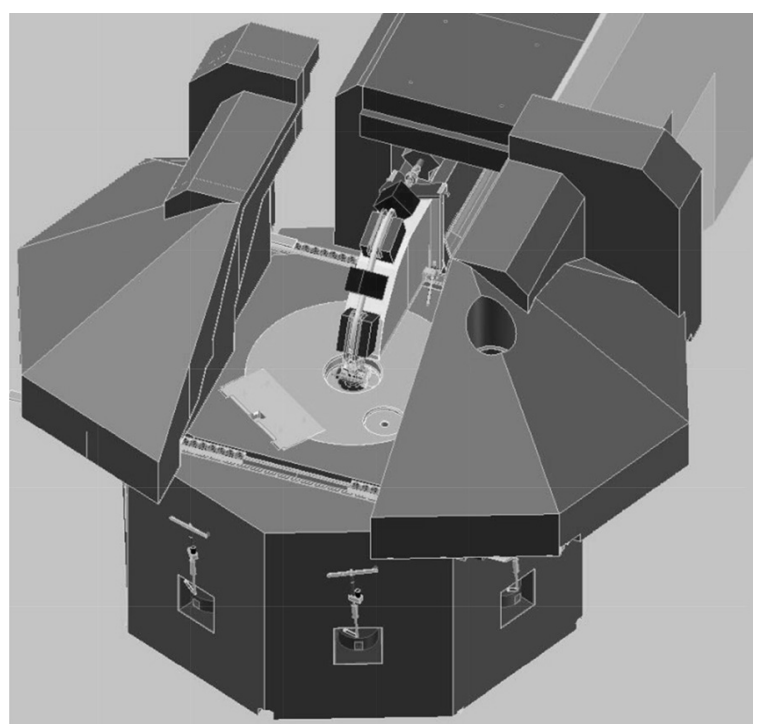

Fig. 4- Neutron Source biological shielding 
generating target plates and fuel assembly for steady state normal operation [11]. According to the results of the analysis of the accidents, it was confirmed that the established safety criteria were not exceeded, however, recommendations were given for the actions of personnel which will be included to the Accident Management Guidance.

Radiation protection calculations. In the framework of review of the technical solutions for establishing biological shielding for the Neutron Source, calculations of biological shielding for the radial part of the SA core were performed. Biological shielding of $S A$ is a system of concrete structures consisting of a radial shield for the core and two sections of upper shield for the electron beam and nuclear subcritical assembly. The basis for the radiation protection calculations (radiation is generated directly by linear accelerator and SA) is energy characteristics and radiation intensity, geometry of the Neutron Source and protective structures. The radiation protection is calculated using the MCNPX code. The analysis showed the adequacy and correctness of the calculations performed in the PSAR [5] on the one hand, and, on the other hand, the fulfillment of the basic requirements for the safety of the personnel that will be located in the experimental room.

\section{Project progress and current activities}

The Neutron Source is being commissioned under License Series EO № 001018 (valid until 01 December of 2020). The license conditions define activities on the Neutron Source commissioning, which require some separate permits (for the first nuclear fuel delivery, physical start-up and trial operation) and define a list of documents for each stages. Currently, all construction activities, installation and functional tests of equipment and systems important to safety have been completed on the NSC KIPT site. The comprehensive test (with dummy fuel assemblies) has been conducted successfully at the end of November 2018. First separate permit for the first nuclear fuel delivery to the NSC KIPT industrial site was issued by SNRIU on 12 April 2019. Fuel has been delivered at the NSC KIPT site in May 2019. The next step now is obtaining the separate permit for the physical start-up. On this way, the NSC KIPT and regulator with TSO are dealing with new tasks and challenges. One of them is updating PSAR based on construction activities and tests. A practical solution of this task primarily depends on hard and careful NSC KIPT work. SNRIU and SSTC NRS are involved in this process due to working interaction with NSC KIPT by providing necessary comments and clarifications. The second one is subcriticality calculations for safety justification of the first core loading. SSTC NRS has proposed approaches to subcriticality calculations for the first Neutron Source core loading. They include options for calculations and appropriate stages of their implementation. In particular, the following three options have been proposed: (1) Realistic approach - All specifications for each fuel pin are given corresponding to its passport data: e.g., enrichment, the mass of 235U, fuel density, core length; (2) Partially Realistic and Conservative approach - Core length for each fuel pin is given conservatively corresponding to its maximal value $(520 \mathrm{~mm})$. All other specifications (enrichment, the mass of $235 \mathrm{U}$, fuel density) for each fuel pin correspond to its passport data. (3) Conservative approach - all specifications for each fuel pin are given: according to passport data: i.e., enrichment $19.907 \%$, the mass of $235 \mathrm{U}$ in the fuel assembly $-42.1 \mathrm{~g}$, fuel density $4.07 \mathrm{~g} / \mathrm{ccm}$, core length $519 \mathrm{~mm}$; or according to technical specifications (DKO) data: enrichment is $19.95 \%$, the mass of $235 \mathrm{U}$ in the fuel assembly $-43.8 \mathrm{~g}$, fuel density is given according to the conservative value in passport data $-4.07 \mathrm{~g} / \mathrm{ccm}$, core length is $520 \mathrm{~mm}$. Based on proposed approaches the following decision were made - calculation for loading first 35 fuel assemblies is performed in accordance with conservative approach. The results of NSC KIPT calculation and SSTC NRS verification calculations meet the regulatory requirements, but slight differences were detected. The calculation models will be validated during the first stage of core loading by comparison results with experiments. The subcriticality calculations for safety justification of the 36-37-38 fuel assemblies loading will be done in accordance with realistic approach after loading first 35 fuel assemblies and models validation. The tentative period for commissioning of the Neutron Source is the end of 2020.

\section{Conclusions}

Construction of a fundamentally new nuclear research facility in Ukraine like the Neutron Source is a challenge for both operating organization (NSC KIPT) and regulatory authority (SNRIU). The regulatory authority SNRIU with SSTC NRS technical support created all the necessary conditions for licensing of the Neutron Source. The regulation «General 
Safety Provisions for the Nuclear Subcritical Facility» was created based on IAEA standards and international experience. Review of the Neutron Source safety justification documents has been performed with high quality level. Moreover, the working interaction between SSTC NRS and NSC KIPT (with informing of the SNRIU) was organized to hurry-up the commissioning process. Independent thermohydraulic, neutronic and radiation shielding models of key nuclear facility elements were developed with further performing the verification calculations of safety studies using non-identical analytical tools.

Notwithstanding with challenges in licensing of the Neutron Source, almost all of them are solved. Nowadays, the Neutron Source is at the final stage of commissioning. The physical start-up is planed by the end of this year.

\section{References}

1. Law of Ukraine «On Nuclear Energy Use and Radiation Safety», No. 39/95-VR dated 08 February 1995 - 1995.

2. IAEA TECDOC-1766. Status of accelerator driven systems research and technology development. Vienna, International Atomic Energy Agency, 2015.

3. M.Kh. Gashev, O.V. Grigorash, A.V. Dolotov, A.V. Nosovsky, O.M. Dybach, A.I. Berezhnoi, O.V. Kukhotsky, (2013). Licensing of the Neutron Source based on the subcritical assembly driven by a linear electron accelerator. Nuclear and Radiation Safety, 4, pp. 3-9.

4. Nuclear Subcritical Facility "Neutron Source Based on the Subcritical Assembly Driven by a Linear Electron Accelerator». Design, NSC KIPT, 2012.

5. Nuclear Subcritical Facility «Neutron Source Based on the Subcritical Assembly Driven by a Linear Electron Accelerator». Preliminary Safety Analysis Report, PSAR, NSC KIPT, 2012.

6. Rearden, B. T., Jessee, M. A., (2018). SCALE Code System, ORNL/TM-2005/39, Version 6.2.3, Oak Ridge National Laboratory, Oak Ridge, Tennessee, Radiation Safety Information Computational Center as CCC-834.

7. NP 306.2.183-2012. General Safety Provisions for Nuclear Subcritical Assemblies, SNRIU, 2012.

8. SSR-3. Safety of research reactors. Vienna, International Atomic Energy Agency, 2016.

9. NRBU-97. Radiation Safety Standards of Ukraine. DHN 6.6.1.-6.5.001-98, Ministry of Health, 1998.

10. License EA 001018 for Construction and Commissioning of Nuclear Subcritical Facility «Neutron Source Based on the Subcritical Assembly Driven by a Linear Electron Accelerator», SNRIU, 2013.

11. INSC U3.01/12. Support to the Ukrainian Regulatory Authorities, Component UK/TS/49 «Licensing of new nuclear subcritical facility - Neutron Source based on an electron accelerator-driven subcritical assembly».

12. Kukhotsky, O.V., Nosovsky, A.V., Dybach, O.M. (2017). Development of thermohydraulic models of core elements of the Neutron Source. Problems of Atomic Science and Technology, 2, pp. 131-137.
Ліцензування ядерної підкритичної установки «Джерело нейтронів»: виклики та шляхи вирішення

\author{
Кухоцький О.В. ${ }^{1}$, Білодід $\epsilon .{ }^{1}{ }^{1}$, \\ Шепітчак А.B. ${ }^{2}$, Немцова C.A. ${ }^{2}$
}

\author{
1 Державне підприємство «Державний \\ науково-технічний центр з ядерної \\ та радіаційної безпеки», м. Київ, Україна \\ 2 Державна інспекція ядерного регулювання \\ України, м. Київ, Україна
}

Дослідницька ядерна установка «Джерело нейтронів, що засноване на підкритичній збірці, яка керується лінійним прискорювачем електронів» наразі знаходиться в стадії введення в експлуатації в Національному науковому центрі «Харківський фізико-технічний інститут» (ННЦ ХФТІ) як міжнародний проект ННЦ ХФТІ і Аргонської національної лабораторії (ANL), США. Джерело нейтронів призначене для вивчення підкритичних систем та генерування нейтронів для використання в прикладних та фундаментальних дослідженнях з фізики, хімії, біології та медицини. Будівництво сучасного об'єкта для ядерних досліджень - Джерела нейтронів - $\epsilon$ викликом як для експлуатуючої організації (ННЦ ХФТІ), так і для регулюючого органу (Держатомрегулювання). ННЦ ХФТІ зіткнувся 3 технічними викликами, зумовленими унікальними конструктивними особливостями об'єкта. Держатомрегулювання зіткнулося 3 двома основними викликами - відсутність нормативної бази з ядерної та радіаційної безпеки для такого типу установок і відсутність досвіду ліцензування такого типу об'єктів. У цій статті розглядаються аспекти, пов'язані з викликами та їх вирішеннями під час ліцензування ядерної підкритичної установки «Джерело нейтронів», зокрема розробка нормативно-правової бази з ядерної та радіаційної безпеки, розгляд документів, що обґрунтовують безпеку для нового об'єкта та виконання верифікаційних розрахунків.

К лючов і слова: джерело нейтронів, експериментальна установка, ліцензування, безпека. 